\title{
Translating on Purpose: Domestication in English Translations of Chinese Publicity Materials
}

Licheng Lu* Faculty of English Language and Culture, Guangdong University of Foreign Studies, No.2 Baiyun Dadao Bei, Guangzhou 510420,
China

Corresponding Author: Licheng Lu, E-mail: lulicheng@gdufs.edu.cn

\section{ARTICLE INFO}

\section{Article history}

Received: November 12, 2018

Accepted: December 19, 2018

Published: January 31, 2019

Volume: 7 Issue: 1

Conflicts of interest: None

Funding: The research is financed by the 2018 Research Innovation Team

"Pragmatic Culture and Identity

Construction" of Guangdong

University of Foreign Studies, China.

\section{Keywords:}

Publicity Materials,

Domestication,

Translation,

Skopos Theory,

Purpose

\begin{abstract}
English translations of Chinese publicity materials play an important role in introducing China to the outside world and in helping foreigners know more and better about the country. Since the implementation of the Reform and Opening-up Policy in China four decades ago, great progress has been recorded in translating Chinese publicity materials into English. However, poor translations still exist, such as those with linguistic errors, cultural inappropriateness, missing of information, inconsistency in the use of proper names, etc. These problematic translations exert a negative impact on China's international image and the cross-cultural communication and exchange between China and the outside world. Under such circumstances, the present study proposes the application of domestication in translating Chinese publicity materials into English from the perspective of Skopos theory. Through illustrations with specific examples, three types of domestication are identified, namely, domestication of culturally-loaded words, domestication of syntactic structures and domestication of rhetorical devices.
\end{abstract}

\section{INTRODUCTION}

Since the implementation of the Reform and Opening-up Policy four decades ago, China has made great achievements in many different fields and is now the second largest economy in the world. Due to China's economic and political influence, an increasing number of foreign corporations have invested in China; the number of foreign students studying in the country has grown dramatically; there are also foreigners who are pursuing their careers in China. On the other hand, China also goes global, establishing diplomatic relationships with more countries; Chinese enterprises have also been promoting their products on overseas markets. Under such circumstances, attention should be paid to English translations of Chinese publicity materials, for they play a decisive role in shaping China's international image and in deepening foreigners' understandings of China.

So far, headway progress has been recorded in English translations of Chinese publicity materials. The translated texts are disseminated via different means of communication, such as radio and television, newspapers and magazines, academic journals and the internet. With the acceleration of globalization and the launching of the Belt and Road Initia- tive, China is going to play an even more influential role in the world; more communications and exchanges will take place between China and the outside world. It is expected that there will be an increasing number of Chinese publicity materials to be translated into English.

However, in reality, not all these translations are satisfactory. Some poor translated works have caused embarrassment, puzzlement or even misunderstandings. Therefore, finding an appropriate strategy to translate Chinese publicity materials into English is of great importance.

\section{CHINESE PUBLICITY MATERIALS AND THEIR ENGLISH TRANSLATIONS}

In the narrow sense, publicity materials refer to the documents made by authorities or professional institutions engaged in external publicity. However, with the strengthening of China's interaction with the rest of the world, almost all walks of life have the task and the responsibility of external publicity. Therefore, publicity materials include all the documents made for the purpose of external publicity in the broad sense. 
Over the years, English translations of Chinese publicity materials have been closely studied. In particular, translators and scholars have been aware of the causes and effects of problematic translations in this area. Yan (2011) pointed out that a translated publicity material fails to achieve the intended effect if the translator does not cater to the ideology and mindset of the target readers, and as a result "external publicity" would be turned into "internal publicity". Sun and Feng (2014) have identified three major problems in Chinese-English translations of publicity materials, namely, providing redundant information, neglecting linguistic and cultural differences, and failing to achieve the intended functions. They proposed that translators should adopt flexible strategies such as shift of point of view, discourse restructuring, addition and deletion as well as rewriting. Cao and Wang (2015) also listed major problems in English translations of Chinese publicity materials, such as grammatical mistakes, use of unidiomatic expressions, inconsistent translations of proper names. After analyzing their causes, they called for the adaption of international standards, proper attention to English readers' ideology and mindset and the shaping of cross-cultural awareness on the part of translators.

To help improve the quality of translations, other scholars have attempted to explore the feasibility of various translation strategies from a wide range of theoretical frameworks. According to Huang (2004), the fundamental features of English translations of Chinese publicity materials are "Three Reflects Principles", which means that the ideal translations should reflect the actual development of China, the target readers' need of information about China, and their mode of thinking as well as linguistic habits. $\mathrm{Hu}$ and Jia (2010) approached the translation of publicity materials from the perspective of Lefevere's Rewriting Theory. They concluded that the whole translation process is manipulated by the mainstream ideology and poetics in a translator's time, and that rewriting is the inevitable outcome. Zhao (2012) based his research on the theory of memetics and concluded that domestication is preferable to foreignization in translating Chinese publicity materials. Xu (2018) studied the translation of publicity materials from the perspective of narratology. She claimed that the mere linguistic conversion is not enough to realize the intended purpose of external publicity which is to construct an ideal international image of China. Implications can be drawn from the field of narratology, for it also emphasizes the effect of "construction". She then recommended two main strategies in light of narratology, namely, selective appropriations and text reconstruction.

Chinese publicity materials, as the term indicates, are used for external publicity. The purpose, or skopos, of translating them into English lies in displaying the great development in Chinese people's political, economic, cultural and social life and helping foreigners know more and better about China's traditional culture, natural landscape, sights of human interests, etc. Therefore, in contrast to the previous studies mentioned above, the present study attempts to prove the credibility of domestication in translating Chinese publicity materials into English from the perspective of Skopos theory.

\section{SKOPOS THEORY AND ITS IMPLICATIONS ON ENGLISH TRANSLATIONS OF CHINESE PUBLICITY MATERIALS}

Traditionally, "faithfulness and "equivalence" were regarded as the most reliable yardsticks in the assessment of a translation. However, in the 1970s, there appeared the Functionalist Approach to Translation in Germany, which shed new lights on translation and switched translation theories from the static linguistic typolologies of translation shifts to a functionalist approach to the analysis of translation (Munday 2001, p.74). The most influential theory of the Functionalist Approach to Translation is the Skopos theory.

The Skopos theory emphasizes the skopos or purpose of the target text on the basis of the source text analysis. It includes three rules: skopos rule, coherence rule and fidelity rule. These three rules are not of equal status. Among them, the skopos rule is regarded as the prime principle in translation.

According to the Skopos theory, translators need to always bear in mind the intended skops in doing the work, and they are justified to adopt any translation strategy that helps achieve the intended skops. In other words, "the end justifies the means" (Reiss and Vermeer 1984, p.96, qtd. by Nord 2001, p.29). In external publicity, the skopos of Chinese publicity materials lies in introducing China to the outside world and helping foreigners know more and better about the country, hence, in translating Chinese publicity materials, the English translations must highlight the readability of the target texts and the response of the target readers. Domestication, in this sense, would be the translation strategy proposed in the present study.

\section{DOMESTICATION IN ENGLISH TRANSLATIONS OF CHINESE PUBLICITY MATERIALS}

In this section, the author will elaborate on how domestication in English translations of Chinese publicity materials works to achieve the intended skopos of external publicity. After close examinations of examples of translated publicity materials, three types of domestication are identified, namely, domestication of culturally-loaded words, domestication of syntactic structures and domestication of rhetorical devices.

\section{Domestication of culturally-loaded words}

The Chinese language is abundant in expressions with unique Chinese characteristics. They are often called "culturally-loaded words". In this study, "culturally-loaded words" are used in the broad sense. They include not only those culturally and politically loaded expressions with typical Chinese characteristics, but also the names of persons, places, dynasties, historical events, etc. These expressions have no equivalents in the English language, posing great difficulties to translators. Consequently, to facilitate target-readers' understandings and ultimately to achieve the intended skopos, translators should 
domesticate the target texts via means of annotation, analogy and so on. Look at the following examples:

(1)

西宁市是青海省的省会。从明清以来, 她就是伊 斯兰教在中国西北部的聚居地和传播中心。

Honored as a smaller Mecca, Xining is the capital city of Qinghai Province. Since the Ming and Qing Dynasties, Xining has been a settlement for Muslims and a center of Islamic faith in northwestern China.

(2)

新浪微博是中国最受欢迎的社交媒体平台之一。 截至 2018 年第三季度, 新浪微博拥有超过 4.45 亿活 跃用户。

Sina Weibo, the Chinese version of Twitter, is one of the most popular social media platforms in China. As of Q3 2018, Sina Weibo has over 445 million active users.

Analogy can help overcome cultural differences and bridge the gap formed in cross-cultural communication. The above two examples have both domesticated the target texts via analogy. Example (1) is taken from the website of a travel agency. In this example, Xining, a Chinese city with strong Islamic background and a huge population of Muslims, is analogized to Mecca, the holy city of Islam and a pilgrimage site for all devout Muslims. As a result, foreign tourists can instantly visualize Islamic mosques, halal restaurants, traditional clothes of Muslims, etc. before they actually join in the trip to Xining. Example (2) is excerpted from a business newspaper article talking about Sina Weibo, one of the most popular social media platforms in China. Social media platforms in China have witnessed rapid development in recent years and come in many types. By analogizing Sina Weibo to the well-known international social media platform Twitter, i.e., by using a domesticated target text, foreign readers will find it easier to understand what they can find and do on Sina Weibo.

\section{Domestication of syntactic structures}

In general, modes of thinking are classified into two major types: the oriental mode of thinking represented by the Chinese one and the occidental mode of thinking represented by Western European and North American ones. These two types are quite different from each other (Lian 2002). The oriental mode of thinking centers on meaning while the occidental one centers on form. This difference is also reflected in the syntactic features of Chinese and English. For instance, the Chinese sentences are often characterized by linear gradation of clauses, in which several clauses are lined up in time order and the relation between them is implicitly indicated by meaning rather than by explicit relation markers. By contrast, the use of strict tree structures is characteristic of English sentences. In English, all parts of the sentences center upon the "Subject+Verb" (SV) structure and their relation is explicitly revealed by distinctive markers (Sun 2009). Therefore, it is difficult to translate Chinese syntactic structures literally into English. Even if they are translated, target readers would find them hard to understand. In view of these difficulties, translators have to domesticate Chinese syntactic structures into the English ones to help achieve the intended skopos. Look at the following example:
(3)

上海银舟大厦位于上海浦东陆家嘴金贸区，东临 主干线源深路, 西临上海钻石交易所, 占地 5, 037平 方米, 楼面面积 37,700 平方米, 高 28 层, 为商贸 结合的高级办公楼。

Located in the center of Pudong's Lujiazui financial zone, the Shanghai Silver Boat Mansion is a 28-storey deluxe commercial and office building, standing on a site of 5,037 square meters with a GFA of 37,700 square meters. It borders on the east the Yuanshen Road, one of the city's main roads, and the Shanghai Diamond Exchange on the west.

In Example (3), the Chinese syntactic structure has been changed a lot in the target text --- the linear gradation of clauses introduced by the italicized and bolded Chinese expressions are reorganized into two SV sentences with participial clause and propositional phrase, which is a typical English syntactic feature.

Parallelism of verbs or verb phrases is another syntactic feature of the Chinese language. In Chinese, it is easy to find a sentence made up of several parallel verbs or verb phrases without any explicit relation markers. In contrast, it is almost impossible to find the same syntactic feature in English, because it goes against the English grammar. A grammatically correct English sentence usually has relation markers between all the verbs, or it has a main verb with other verbs turned into secondary structures through the use of propositions, as is the case in Example (4).

(4)

中国的经济成功地进行了 “软着陆”, 这是宏观经 济调控的结果。它控制了通货膨胀, 避免了经济的大 起大落, 保持了经济的快速增长。

The Chinese economy has successfully made a "soft landing", a result of macro economic control, which has curbed inflation while maintaining rapid economic growth without major fluctuations.

In Example (4), two sentences in the source text have been combined into one single sentence in the target text through the use of an attributive clause introduced by "which". Moreover, the three parallel verbs 控制 “(curb)”, “免(avoid), and “保持 (maintain)” in order of appearance in the source text are turned into only one main verb “控制 (curb)" with one participle "maintaining" which was derived from the verb “保持(maintain)” and was moved to the second place, and one proposition "without" which was used in place of the verb “避免(avoid)” in the target text.

\section{Domestication of rhetoric devices}

The Chinese language is known for its frequent use of flowery and pompous adjective and noun phrases. If the flowery adjective and noun phrases in Chinese sentences were to be translated literally into English, it would pose great difficulties to translators because there are too many modifiers and it is easy to cause repetition and monotony in the translations. Moreover, it would affect target readers' understandings as the translations may contain redundant information and hinders target readers' identification of core information. Therefore, translators should domesticate the target texts via deletion or adaptation to ensure the rendering of core infor- 
mation and the proper understanding on the part of target readers. Look at Example (5):

(5)

保护区内植被丰茂，林木苍翠，浓荫蔽日， 古树参天, 老藤悬于峭壁, 苔藓附于怪石, 幽兰依于 岩畔, 绿柳垂于溪涧, 处处是生物的世界, 绿色的世 界。在这样的生态环境里, 万类生物竟自由，鹰鹤朝翔于 天际, 锦鳞畅游于水中, 顽猴嬉戏于竹海, 百鸟啼鸣于林 间, 俨然是一 座生机勃勃, 生意盎然的 “自然生物博物 馆”

The Nature Reserve is densely covered with abundant vegetation and forests. Within the boundaries of this "Natural and Ecological Museum", all living beings enjoy their fullest vitality.

In Example (5), the Chinese text is piled with a list of adjective and noun phrases to describe the vitality of the nature reserve with a large number of plantations and animals indicated by the italicized and bolded sections. These adjective and noun phrases in the Chinese text, in parallel structures, offer detailed information about the plantations and animals on the one hand and a sense of musicality on the other hand. But translating all these expressions into English will make the target text full of redundant information which affects the achievement of the intended skopos. Therefore, the translator omitted the long list of adjective and noun phrases about all the specific examples of plantations and animals, leaving only the generic terms "abundant vegetation and forests" and "all living beings", which rendered the core information and maintained the conciseness and clarity of ideas in the target text.

(6)

当风和日丽时, 站在广州塔上举目远望, 越秀山, 白云 山，长洲岛隐隐可见，真有 “登泰山而小天下”之感。

On a day of gentle breeze and bright sunshine, the observation deck of the Canton Tower commands an indistinct view of Yuexiu Mountain, Baiyun Mountain and Changzhou Island far away. Standing on the deck, one gets the feeling that the world below is suddenly belittled.

The use of proverbs or idioms is another rhetoric feature of the Chinese language. In Chinese, the use of proverbs or idioms can achieve the effect of "concise expressions with profound meanings". However, it might leave English native speakers with the impression that Chinese speakers lack originality (Matalene, 1985). Moreover, translating proverbs and idioms "faithfully" into the target text may affect target readers' understandings of the intended messages. In Example (6), the proverb “登泰山而小天下” literally means "Standing on top of Mount. Tai in eastern China, one gets the feeling that the world below is suddenly belittled." It is used here to show the height of the deck of the Canton Tower. If the translator had rendered “登泰山而小天下” according to its denotative meaning, the target readers would feel puzzled --- We are in Guangzhou in southern China, aren't we? Can anyone tell us how come there is "Mount. Tai" in southern China? Thus, to cater to foreign readers' need of the intended message, the translator has used a domesticated text "Standing on the deck, one gets the feeling that the world below is suddenly belittled." in which the connotative meaning of "height" is used instead of its denotative meaning "Mount. Tai in eastern China".

\section{CONCLUSION}

English translations of Chinese publicity materials are indispensable to the mutual understandings between China and the outside world. From one language into another, the translation process seems to be a simple interlingual conversion, but is actually a result of sufficient linguistic and cultural considerations. In order to optimize the communication and dissemination effect of Chinese publicity materials, the English translations should above all be in conformity with the skopos rule, because in the Skopos theory the skopos of translation determines the translation methods and strategies that are to be employed in order to produce a functionally adequate result (Munday 2001). Through the analyses and illustrations in this study, it is concluded that domestication in the English translations is not only justifiable but also effective in achieving the intended skopos of Chinese publicity materials.

\section{REFERENCES}

Cao, R.Y. \& Wang, Y. (2015). Translations of Chinese Publicity Materials: Problems and Solutions. Shandong Social Sciences. 5, 321-323.

Hu, F.Y. \& Jia, W.B. (2010). China's External-oriented Propaganda Translation: A Rewriting Manipulated by Ideology. Shanghai Journal of Translators. 1, 23-28.

Huang, Y.Y. (2004). Application of "Three Reflects Principles" in the Translations of Publicity Materials. Chinese Translators Journal. 25(6), 27-28.

Lian, S.N. (2002). A Contrastive Study of Chinese and Western Modes of Thinking. Foreign Languages and Their Teaching. 2, 40-46.

Matalene, C. (1985). Contrastive rhetoric: An American writing teacher in China. College English, 47, 789-808

Munday, J. (2001). Introducing Translation Studies. London and New York: Routledge.

Nord, C. (2001). Translating as a Purposeful Activity: Functionalist Approaches Explained. Shanghai: Shanghai Foreign Language Education Press.

Sun, L. (2009). Effects of Chinese and Western Modes of Thinking on College Students' English Writing. Journal of Capital University of Economics and Business. 5, 113-117.

Sun, X.Y. \& Feng, Q.H. (2014). On the Translation of Foreign Publicity Materials of Enterprises from the Perspective of Skopos Theory. Foreign Language Research. 4, 98-102.

$\mathrm{Xu}$, H. (2018). Publicity Translation: Implications from Narratology on Translators' Operations. Journal of PLA University of Foreign Languages. 41(3), 123-130.

Yan, Y. D. (2011). A Study on China's Global Communication under the Background of Globalization. Journal of Fujian Normal University (Philosophy and Social Sciences Edition). 2, 103-107.

Zhao, S.Y. (2012). Memetics and Publicity Translation. Journal of Shanxi University (Philosophy \& Social Science). 35(2), 137-140. 